\title{
MEANS OF FORMATION OF PROFESSIONAL REFLECTION OF FUTURE ELEMENTARY SCHOOL TEACHERS DURING THE EDUCATIONAL PROCESS AT PEDAGOGICAL COLLEGE
}

\section{N. Denha}

A.S.Makarenko Pedagogical College of Kremenchuk

vul. Lizy Chaikinoi, 33, Kremenchuk, Poltava Region, 39623,Ukraine. E-mail: denga_n@ukr.net

Purpose. To define, substantiate and characterize the means of successful formation of professional reflection of future elementary school teachers during the educational process at the pedagogical college. Methodology. We used the methods of theoretical analysis, synthesis and generalization, observation of upbringing and educational activities, questionnaires and testing of students of the pedagogical college. Results. The psychological and pedagogical means of formation of professional reflection of students in the system of preparation of future elementary school teachers are grounded and characterized in the article. Originality. The effective psychological and pedagogical means of formation of professional reflection of future teachers of elementary school (individual reflection (technique of repetition, counseling, individual reflexive games, solution of reflective tasks, reflexive analysis of classes) were revealed and characterized, collective means of development of teacher's professional reflection (reflexive debates, reflex interviews, reflective sessions, consilium, workshop, group reflection games, reflexive exercises, training for the development of professional pedagogical reflection)) and specifics of their application in the educational process of pedagogical college have been disclosed (preliminary instruction of teachers/tutors and group curators about the gist, content and methods of use of reflexive means and the validity of their selection according to the type of lesson, educational subject, lesson form). Practical value. We have a generalized list of means for forming the professional reflection of future primary school teachers and the specifics of their use for the further implementation into the educational process at the pedagogical college.

Key words: reflection, professional reflection, pedagogical reflection, types of reflection, educational process, psychological and pedagogical means.

\section{ЗАСОБИ ФОРМУВАННЯ ПРОФЕСІЙНОӤ РЕФЛЕКСЇ̈ МАЙБУТНІХ ВЧИТЕЛІВ ПОЧАТКОВИХ КЛАСІВ ПІД ЧАС ОСВІТНЬОГО ПРОЦЕСУ ПЕДАГОГІЧНОГО КОЛЕДЖУ}

\section{Н. М. Деньга}

Кременчуцький педагогічний коледж імені А.С. Макаренка

вул. Лізи Чайкіної, 33, м. Кременчук, Полтавська обл., 39623, Україна. E-mail: denga_n@ukr.net

Проведено аналіз змісту й установлення сутності понять «рефлексія» та «професійна рефлексія». Методологія. На основі застосування методів теоретичного аналізу, синтезу та узагальнення, спостереження за навчальною та виховною діяльністю, анкетування та тестування студентів педагогічного коледжу визначено, обгрунтовано та схарактеризовано психолого-педагогічні засоби формування професійної рефлексії студентів у системі підготовки майбутніх учителів початкової школи. Зокрема, це засоби індивідуальної рефлексії (техніка повтору, консультування, індивідуальні рефлексійні ігри, вирішення рефлексійних завдань, ведення щоденника рефлексії, рефлексія в кінці заняття, рефлексійний аналіз заняття) та колективні засоби розвитку професійної рефлексії викладача (рефлексійні дебати, рефлексоінтерв'ю, рефлексійні заняття, консиліум, практикум, групові рефлексійні ігри, вправи на розвиток рефлексії, тренінг із розвитку професійної педагогічної рефлексії)). Результати. Доведено необхідність формування професійної рефлексії майбутніх вчителів початкових класів як складової їх професійної підготовки та визначено особливості ії формування під час навчальної діяльності, виховної роботи та проходження педагогічної практики. Розкрито специфіку застосування засобів формування професійної рефлексії студентів під час освітнього процесу педагогічного коледжу (попередній інструктаж викладачів і кураторів груп щодо сутності, змісту й методики використання рефлексійних засобів та обгрунтованість їх вибору у відповідності до виду заняття, предмету викладання, форми проведення заходу). Практичне значення. Запропоновано внесення змін до робочих програм навчальних дисциплін з метою формування у студентів педагогічного навчального закладу вмінь аналізувати рівень власних знань, умінь, навичок, оцінювати свій навчальний досвід, корегувати власний професійний розвиток.

Ключові слова: рефлексія, професійна рефлексія, педагогічна рефлексія, види рефлексії, освітній процес, психолого-педагогічні засоби.

PROBLEM STATEMENT. In the context of the key reform of the Ministry of Education and Science, the new Ukrainian school will need a teacher capable of professional and personal growth that is able to choose educational materials, improvise and experiment. That is, he should determine the way he should go with the students in order to achieve the results defined in the State standard. The teacher must, on an innovative basis, plan a professional pedagogical activity and predict its results. It motivate the teacher to creative search, to improve professional competence, to independently make the necessary adjustments to the pedagogical process, taking into account the goal set, the need for reflection. Professional pedagogical reflection is a peculiar technology that allows to objectively analyze the experience, to organize it, to understand and to use the experience of others in the activity, which determines the value-determined attitude of the teacher to the profession, which is an important part of the successful training of students and incipience at the first working place as a professional after that. There 
fore, there is need for the formation of professional reflection of future primary school teachers.

MATERIAL AND RESEARCH RESULTS. To study the issue of forming a professional reflection of future elementary school teachers, it is important to analyse the content and the establishment of the essence of the concepts of "reflection" and "professional reflection". In the dictionary of philosophical terms, reflection (lat. Reflexio - bend, reflection) is interpreted as an act of cognition, the subject of which is the cognitive activity of consciousness, "I". The cognition can be studied through the results - the change of scientific ideas, the theories - the objective method, or through the analysis of the subjective activity of knowledge reflection [22].

In particular, in the explanatory dictionary, "reflection" is defined as self-examination, the reflection of a person over his own state of mind [17]. J. Richards [27], N. Hatton [25], G. Shchedrovitsky [23] and other authors tried to formulate the concept of reflection.

The formation and development of ideas of reflexion in modern philosophy are considered by such researchers as V. Bazhanov, A. Ogurtsov, I. Semenov, V. Shvirev and others. The research of the specificity of personal reflexive procedures and the nature of the knowledge obtained with their help was conducted by V. Lectorovsky.

The reflexion as a mechanism of self-development of a person, a professional resource, a condition for the establishment of professionalism was studied by G. Andreyev [1], U. Dzhashilikova [7], S. Druzhilov [8].

In many works of modern scientists, the phenomenon of professional reflection is explored directly or in connection with the study of other problems. The essential content of professional reflection is grounded in the researches of such authors: Y. Ponomareva [13], and others; The structure is explored: Y. Kulyutkin [12], G. Shchedrovitsky [23]; The mechanisms of the reflection process are revealed: O. Anisimova [2], E. Isaev [11], G. Sukhobska [18], and others.

Professional reflexion was studied by O. Berestchenko [4] (on the example of a culture of professional communication of a specialist), N. Sas [15] (on the example of the professional activity of heads of educational institutions); the questions of the professional reflection of the teacher were the subject of attention of I. Bech [5], I. Zimnaya [9], V. Semichenko [16] , M. Kelly [26], T. Farrell [28].

M. Kelly [26] emphasizes on the fact that the reflection of the teacher is a key component of his professional growth and should become part of the career of each teacher.

Among numerous definitions of reflection, in terms of studying the professional reflection of employees of educational institutions (including primary school teachers), the definition of A. Khutorsky, according to which reflection - thought activity, sensory experience - is the process the subject of the education realizes his activities [21].

I. Zimnya [9] tend to think that professional reflection is the development of the proficiency, the capabili- ties of the teacher, his professional competence. In our opinion, with the help of reflection the teacher is able to manage a professional activity, move from difficulties to their analysis and finding a way out of a difficult situation.

Y. Babayan, K. Nor point out that reflection is the most important professionally significant quality of the personality of the teacher, which along with empathy and dynamism determines the level of his professional suitability [3].

A. Bizyayev defines the pedagogical reflection as "the process of imaginary (preliminary or retrospective) analysis of any professional problem, which results in a personally colored understanding of the essence of the problem and new perspectives for its solution" [6].

T. Yablonskaya determines pedagogical reflection as an understanding of the preconditions, patterns, and mechanisms of their own activities, the appeal to their inner world, the experience of life, which determines the conscious value-determined attitude of the teacher to the profession, to himself, and hence its values for him [24]. I. Zimnya makes a connection between the teacher's reflection and the professional self-awareness of the teacher as a subject of pedagogical activity [9].

In order to study the level of development of professional reflection in future primary school teachers we conducted a diagnosis among the students of pedagogical college of the specialty "Primary Education", the educational degree "Bachelor". A total of 102 students participated in the diagnosis. Among them, there are 49 full-time students and 53 full-time students.

The method of diagnostics of reflexivity (author A. Karpov, adapted for students) showed that the average level of reflexivity is $33 \%$ and the low level of reflexivity $-67 \%$ of the respondents.

The method of determining the level of reflection (author A. Anisimov, adapted for students) made it possible to determine that $24 \%$ of students have a lower average level of reflexivity, the average is $52 \%$, the average is $14 \%$, the high is $10 \%$; below average selfcriticism was received by $29 \%$ of the respondents, the average $-43 \%$, above the average $-14 \%$, high $-14 \%$; below the average level of collectivity in $29 \%$ of respondents, the average $-52 \%$, above the average $14 \%$, high $-5 \%$.

The results of the diagnosis show that it is necessary for the educational process to include various psychological and pedagogical means that contribute to the formation of professional reflection.

A teacher who is capable of reflection improves himself not only as a teacher but also as a person, because he re-reflects not only professional activity but also his inner world, understands its imperfections, tries to improve, strengthen his own spirituality.

I. Zyazun notes that only one can be a teacher who possesses the technology of pedagogical reflection [10]. Thus, an important condition for the development of the competence of the future elementary school teacher is the purposeful and substantiated formation of the student's professional reflection.

The peculiarity of the professional reflection of the teacher is that while organizing the activities for stu- 
dents, the teacher tends to look at himself and his actions as if he is the eyes of his pupils, take their opinion and views into consideration, imagine their inner world, try to "feel" the pupil, understand his emotional state. By predicting the interaction the teacher assesses himself as a participant of this interaction, a participant of the dialogue. At the same time it is the teacher who creates the conditions for the emergence of intersubjective relations of participants of pedagogical process. In the process of pedagogical reflection the teacher identifies himself with the actual pedagogical situation, with one or another content of pedagogical interaction, with the pupil, with his colleagues, with different models of pedagogical activity, various pedagogical technologies and others.

According to the direction of reflexion assessments within communicative act we distinguish personal reflection (the self-study of the subject which results in the rethinking of man himself and his relationship with the world), mutual reflection (the process of double, mutual mirror reciprocation of the subjects, the content of which is the reproduction of features of each other) and group reflection.

With the reflection of his activities a person realizes: "What do I/we do in reality?" and tries to identify difficulties and find ways to overcome them.

Each higher educational institution carries out educational and upbringing work, which in complex form the educational process. In accordance with the Law of Ukraine "On Higher Education", the educational process is an intellectual, creative activity in the field of higher education and science that is being carried out at a higher education institution (scientific institution) through a system of scientific, methodological and pedagogical activities and is aimed at the transfer, assimilation, multiplication and use of knowledge, skills and other competencies of the learners, as well as the formation of a harmoniously developed personality "[14].

In our opinion, the formation of professional reflection of future primary school teachers should be conducted during educational activities, educational work and pedagogical practice.

Reflective component of student's educational activity marks the ability to analyze the level of his own knowledge, abilities, skills; to highlight the advantages and disadvantages (in relation to groupmates), to evaluate their learning experience, to formulate the results obtained. In this case, the student's personal reflection is not only the result of the work but also a starting point and an incentive for a new educational activity, the formulation of new goals.

K. Fopel [20] distinguishes the following types of reflections: reflection without help, reflection of selfdevelopment; reflection on feedback received from other people; reflection at the end of any group activity. All these types of reflection can be conducted during classes.

Reflection without third-party assistance helps students balance their own strengths and weaknesses, outline the goal of further work, adjust professional development, develop a self-development program, and so on.
It is sometimes useful to analyze your learning experience and draw conclusions without discussing anything with others. This can happen in different ways. For example, general silence for some minutes provides an opportunity for personal analysis. Another option is to record your own thoughts. During "reflection without help," its subject mentally or in writing answers the question: what I have understood ... that I have not understood ... what I would like to change...

During the learning process there are always situations when the behavior of any of the participants is being discussed. Anyone whose actions are commented by the teacher may think about the things that caused this feedback, as well as the supplement or deepen the understanding of their own actions. This is an example of reflection in relation to the feedback received from other people.

When summarizing at the end of classes (especially practical, laboratory work), participants can analyze what they have been able to achieve, what were the benefits or limitations of the work that need to be considered for the future - an example of reflection at the end of the group activity.

These types of reflections can give everyone the opportunity to compare his behavior, his way of thinking, the level of knowledge with the behavior, thoughts and educational achievements of others. Participants will be able to decide what can be summarized by this comparison. At the same time there are always characteristic answers: "I am happy with my actions ... In this area I would like to study ... Next time I would like ...".

Reflection helps student to formulate the obtained results, to determine the goals of further educational work, to adjust his path to study at the institution. It is possible to conduct it at the beginning of the class with the help of typical activities for all kinds of reflection: the assumption about the presence of certain qualities, motives, correct and false actions ("possible", "maybe", "in my opinion", "it is worth to assume" ) or about what others can think of them; doubt ("I doubt", "not sure"); a question to yourself; settings for changing the behavior and relationships with students ("we need to be more demanding"), etc.

The reflection of self-development as an individual takes place when participants of the educational process try to compare their behavior in a particular situation and their personal development. They reflect on what they thought, felt or did in this situation, how they respected the old ways of responding, how often something new appeared [24].

In order to form professional reflection of students that study the specialty "Primary Education" it is expedient to use a number of psychological and pedagogical means during educational work.

In our opinion there are means of individual reflection (techniques of repetition, counseling, individual reflexive games, solving reflexive tasks, keeping a diary of reflection) and collective means of development of professional reflection of the teacher (reflexive debates, reflexive interviews, reflexive classes, consiliums, workshops, group reflection games, training on the development of professional pedagogical reflexes)).

There are a number of exercises aimed to develop the 
professional competences of the future teacher who is ready for reflection, who realizes professional knowledge and skills, rethinks stereotypes of his own behavior, approves the decisions, plans and organizes professional activity, who is ready for creative work, capable of self-evaluation, self-examination, selfknowledge and self-actualization, understands the internal state and causes of another person's the behavior, the mechanisms of organization of collective activity, coordinates various social roles in the group.

The exercises that should be used for students at the training on professional reflection formation, classes, educational hours: "My purpose", "Glow success", "Flower of success", "Self-portrait", "Without mask", "Carousel", "Quality", "Commission store", " Where do I go?", projective drawing "I am just the one I am", "Three names", figurative-reflection procedure "Tree", figurative-reflective exercise "Give yourself a name", "Tree of purpose ", "Dishwasher ", " Work in groups", "Glass doors ", "Reflection by the circle ". These exercises are performed in pairs or in groups. The tasks of these exercises are various:

-describe yourself to an unknown person (appearance, stroke, style of speaking, style of clothing);

- with out preliminary preparation complete the phrase; - to find out state, moodand feelings of one of the participants by means of questions the answer for which is "Yes";

- togeteasilyintouch, getacquainted, supportconversationandsaygoodbyetothenextmeetingwith an unknown person;

- todefinethebestandthe worstqualitiesandtoplacetheminthedegreeofsignificance;

- rate theplaceat a ten-pointscale;

- towritedownthreevariantsofthenameandtocharacterizeoneselfaccordingtothegivennames;

- to think of your self as a tree and describe it;

- draw a tree symbolizing the scale of achievements, and mark the place where the participants;

- to think of your self as a disband give clear instructions for its care;

- to actas a tutor (to give a task) or a pupil (to perform a given task);

- to describe the place and time of the next meeting with out word sand at a distance to the group mate;

- to complimented a couther;

- to draw the sun and write the components of professional successonitsrays;

- to draw the sunand write the components of professional successonitsrays;

- to draw a flower and write downobsta cleson the way to success on the back of its petals;

- draw a circlethatschematicallymeansthedayanddivideitintopartsthatdeterminetheamoun-

toftimespentonstudying, family, friends, rest, homework, etc;

- toanswerthequestionsrelatedtothemostimportantthing/caseatthetimefortheparticipant;

- complete the text about the things that the participants worry about the most;

- discuss the quotes off amous people.

Group curators or class teachers can use such form of activity as reflexive debates during educational clas- ses. This will enable to solve the problem situation by analyzing the given problem situation, issues to identify the problem and the necessary actions to solve it, build a line of defense of their point of view, analyze the ongoing debate process, and form students' professional reflection skills.

During classes, educational and scientific events, it is expedient to use a reflexive interview (refinterview) or a reflexive listening - a feedback to a person who is speaking. This will allow students to clarify what they have heard and analyze what the speaker has said. The usage of the questions like "What did you want to say about this?", "I did not understand what you mean?", "Is this all you wanted to say?","Could you repeat again?" or the following phrases: "In your opinion, ...", "As I have understood, so ...", "In other words, you think ..." and the expressions such as: "Probably, you feel ...","It seems to me that now you feel ...", " To summarize the things you have said, then ... ","Your main ideas are ..." will allow the student to form the skills of analysis of the things they have heard and said. These skills are essential for the further professional activity of the elementary school teacher.

Both in educational and academic activities, it is particularly important to use such psychological and pedagogical means of forming the professional reflections:

- areflectionworkshopthatallowsyoutoconductananalysisoflearningactivitiesandpersonalqualitiesas a responseto a number of important questions;

reflexive games give the opportunity to learn how to identify the motives of another's actions and analyze their behavior through the taking a role by a participant in solving a simulated problem situation, as well as conducting a subsequent group analysis of the actions that took place during the course of the course;

a reflection consilium in the form of discussion by a group of students of a particular problem, its analysis, the search for effective solutions.

However, after analyzing the curriculums of the disciplines studied by students at pedagogical college, we saw that the professional reflection in the professional training of the elementary school teacher was not purposefully considered, with the exception: the professional reflection in pedagogical psychology is mentioned in the study of the issue "General bases of pedagogical activity", in the age psychology the meaning of "reflection" in the theme "Junior school age" is mentioned, self-analysis of activity in the topic "Selfeducation of the future teacher" (discipline "Introduction to specialty ") is considered. In our opinion, it is necessary to include the study of the concept of professional reflection into a number of disciplines. For instance, while studying the methodology of teaching mathematics in elementary school, it is expedient to include the question "Professional reflection of the teacher of elementary school" into the topic "General questions of the methodology of mathematics". It is most efficient to include the issue of developing professional reflection in the first lecture on this topic, along with the study of such issues as "Planning the educational process in primary school", "From the history of the classroom system", "The purpose of 
teaching Mathematics in elementary school", "Requirements to the lesson of Mathematics in elementary school", "Features of an effective lesson of mathematics in elementary school", "Teacher training for a lesson", "Types of mathematics lessons", "The approximate structure of the Mathematics lesson and its methodology", "General characteristics of learning approaches", "Classification of methods of teaching Mathematics in elementary school", "Characteristics of the main methods of teaching", "Age characteristics of the students at the age of six". This will enable students to master the concepts of pedagogical reflection, the types and structure of pedagogical reflection, the ability to analyze the level of their own knowledge, abilities, skills, assess their learning experience, formulate the obtained results, form a "balance" of their own strengths and weaknesses, outline the purpose of the further activity, adjust their professional development, apply in the training and further professional activities individual and collective means of development of professional reflection of the teacher, develop a selfdevelopment program along with other knowledge and skills.

Since the qualities that students need for their future professional activity are most successfully formed during the teaching practice, to develop the professional reflection of future elementary school teachers it is expedient to introduce reflexive analysis of the lesson during the student's passage of pedagogical practice, which includes a number of the following questions:

- Wasmystrategysuccessful? Howcouldbe thelesson builtdifferentlytomakeitmoreeffective?

- Have my students learned anything new at the lesson? If so, then what owing to? If not, what is the reason?

- Was there anything special at the lesson? If so, what was it exactly and why?

How much does my lesson rely on knowledge, experience and interests of students? How could I do it better?

Did I manage to keep discipline in the classroom? Which of my classroom strategies worked better, which of them worked worse? Why? What should be done differently?

What did I understand and realize in the art of learning as the result of this lesson? What do I need to do to become a successful teacher?

The reflective analysis of the lesson allows students to master the technology of reflective thinking.

CONCLUSIONS. Thus, as the result of application of the methods of theoretical analysis, synthesis and generalization, observation of academic and educational activities, questioning and testing of students of pedagogical college, the psychological and pedagogical means of formation of professional reflection of students in the system of preparation of future elementary school teachers are grounded and characterized in the article. We consider the development of a model for the formation and development of professional reflection in future primary school teachers promising.

\section{LITERATURE}

1. Andreeva G. Social psychology today: searchesandreflections / G. Andreyeva. - M.: MPSI, 2009. - 160 p.

2. Anisimov O. S. Acmeological bases of the reflexive self-organization of the teacher: creativity and culture of thinking: author. dis ... doc. psychologist Sciences / O. S. Anisimov. - M., 1994. - 86 p.

3. Babayan Y. O. The Structure of the Reflexive Competence of a Teacher of High School / Yu. O. Babayan, KF Nor // Collection of Scientific Papers: Psychological Sciences. - 2006. - No. 2 (13). pp. 24-26.

4. Berestenko O. G. Culture of professional communication: textbook / O.G. Berestchenko. - Lugansk: DZ "LNU named after Taras Shevchenko", 2013 - 300 p.

5. Bech I. D. Reflection in the spiritual selfdevelopment of personality / I. D. Bekh, G. M. Lysitsa // Pedagogics and psychology. Bulletin of the National Academy of Sciences of Ukraine.- K.: PJSC "Publishing House" Kyivska Pravda ". - P. 37.

6. Bizyayeva A. A . Psychology of Thinking Teacher: Pedagogical Reflection / A. A Bizaziev. Pskov: PGPI, 2004. - 216 p.

7. Dzhaksylykova U.S. The role of reflection in the professional development of the teacher [electronic resource] / U.S. Jaksylykova - Retrieved from: http://zkoipk.kz/2015smart1/1282-conf.html.

8. Drujilov S. A. Individual resource of professional development as an essential condition for the development of professionalism of a person / S. A. Druzhilov // International Journal of Applied and Fundamental Research. - 2010. - No. 5 - P. 145-148.

9. Zimnaya I. A. Pedagogical Psychology: textbook for high schools / I. A. Zimnaya. - M.: Logos, 2000. $383 \mathrm{pp}$.

10. Zyazun I.A. Pedagogical Proficiency: Textbook (2nd Edition., Proceedings.) / I. A. Zyazyun, L. V. Kramuschenko, I. F. Kryvonos. - K.: Higher school, 2004. - 422 p.

11. Isaev E. I. Formation and development of professional consciousness of future teacher / E. I. Isaev, S. G. Kosaretsky, V. I. Slobodchikov // Vopr. psychology - 2000. - No.3. - P. 57-66.

12. Kulyutkin Y. N. Education of adults: sociopsychological problems, searches, solutions / Y. N. Kulyutkin, G. S. Sukhobskaya. - St. Petersburg: IW RAO, 2000. - 184 p.

13. Ponomarev O. S. Model of professional activity of a specialist: [text of a lecture] / O. S. Ponomarev. Kh.: NTU "KhPI", 2006. - 36 p.

14. About higher education [Electronic resource]: Law of Ukraine dated July 1, 2014 № 1556-VII // The Verkhovna Rada of Ukraine: officer. web portal. Text. Data - Kyiv, 2014. - Retrieved from: http://zakon3.rada.gov.ua/ laws / show / 1556-18 / page 6

15. Sas N. N. Professional reflection as a criterion for the effectiveness of vocational training for innovative management in the conditions of the master's degree "Specific categories. Management of Educational Institutions "/ N. N. Sas // Articles and reports of participants of the international scientific and practical conference" Innovative development - from J. Schum- 
peter to the present: economy and education "Kaluga, October 1-2, 2015 - M.: Publishing house "Scientific consultant", 2015. - pp. 352-354.

16. Semichenko V. A. Psychology of personality / V.A. Semichenko. - K.: Publisher Eshke, 2001.

17. The Ukrainian language dictionary: 11 volumes / ed.: I. K. Billodid; Academy of Sciences of the USSR, Institute of Linguistics. named after O. Potebni. - K.: Science. thought, 1978. - T. 9 - S. 2.

18. Sukhobskaya G. S. Andragogical orientation of vocational and pedagogical education: sociocultural prerequisites [electronic resource] / G. S. Sukhobskaya, T. V. Shadrin. - Retrieved from: http:// ext. spb. ru/ index. php/2011-03-29-09-03-14/108-custom-person.

19. Fetiskin N. P., Kozlov V. V., Manuilov G. M. Social and psychological diagnostics of the development of personality and small groups. - Moscow, 2002. $-490 \mathrm{p}$.

20. Fopel K. An effective workshop.Dynamic Learning / K. Fopel. - M.: Genesis, 2003. - P. 52-53.

21. Khutorskaya A. V. Contemporary didactics: textbook for high schools / AV Khutorskaya. - St. Petersburg: Peter, 2001. -544 p.

22. Shynkaruk V. I. Philosophical Dictionary /
V. I. Shynkaruk. - 2nd edition, add. - K.: Heads. Ed. URE, 1986. - 800 p.

23. Shchedrovitsky G. P. Reflexion and its problems / G. P. Shchedrovitsky // Reflexive processes and management. - 2004. - No.2, T. 4. - P. 72-77.

24. Yablonskaya T. M. The pedagogical reflection training for students and teachers / T. M. Yablonskaya // Practical psychology and social work. - 1999. No.3. - P. 9-12.

25. Hatton N. Reflection in teacher education: Towards definition and implementation / N. Hatton, D. Smith // Teaching Education. - 1995. - No 11 (1). - P. 33-39.

26. Melissa Kelly. Importance of Teacher Reflection [electronic resource] / Kelly Melissa. - URL: https://www.thoughtco.com/importance-of-teacherreflection-8322.

27. Richards J. Beyond training: Approaches to teacher education in language teaching / J. Richards // Language Teacher. - 1990. - No 14 (2). - P. 3-8.

28. Farrell T. Reflective teaching / T. Farrell // Forum ELT Journal. - 1998. - № 4. - P. 10-18.

\section{СРЕДСТВА ФОРМИРОВАНИЯ ПРОФЕССИОНАЛЬНОЙ РЕФЛЕКСИИ БУДУЩИХ УЧИТЕЛЕЙ НАЧАЛЬНЫХ КЛАССОВ ВО ВРЕМЯ ОБРАЗОВАТЕЛЬНОГО ПРОЦЕССА ПЕДАГОГИЧЕСКОГО КОЛЛЕДЖА}

\section{Н. М. Деньга}

Кременчугский педагогический колледж имени А.С. Макаренко

ул. Лизы Чайкиной, 33, г. Кременчуг, Украина, 39623. E-mail: denga_n@ukr.net

На основе применения методов теоретического анализа, синтеза и обобщения, автором статьи определено, обосновано и охарактеризовано психолого-педагогические средства формирования профессиональной рефлексии студентов в системе подготовки будущих учителей начальной школы. В частности, это средства индивидуальной рефлексии (техника повторения, консультирование, индивидуальные рефлексионные игры, решения рефлексивных заданий, ведения дневника рефлексии, рефлексия в конце занятия, рефлексионный анализ занятия) и коллективные средства развития профессиональной рефлексии преподавателя (рефлексионные дебаты, рефлексоинтервью, рефлексионные занятия, консилиум, практикум, групповые рефлексионные игры, упражнения на развитие рефлексии, тренинг по развитию профессиональной педагогической рефлексии)).

Ключевые слова: рефлексия, профессиональная рефлексия, педагогическая рефлексия, виды рефлексии, образовательный процесс, психолого-педагогические средства.

\section{REFERENCES}

1. Andreeva, G. (2009), Social'naja psihologija segodnja: poiski $i$ razmyshlenija [Social psychology today: searches and reflections], MPSI, Moscow, Russia.

2. Anisimov, O.S. (1994), "Acmeological bases of the reflexive self-organization of the teacher: creativity and culture of thinking", Author. dis ... doc. psychologist Sciences, Moscow, Russia.

3. Babayan, Y.O., Nor, K.F.(2006), "The Structure of the Reflexive Competence of a Teacher of High School", Collection of Scientific Papers: Psychological Sciences, No. 2(13), pp. 24-26.

4. Berestenko, O.G. (2013), Kultura professyonalnoho obshchenyia: Uchebnoe posobye [Culture of professional communication: textbook] / O.G. Berestchenko. - Lugansk: DZ "LNU named after Taras Shevchenko", 2013 - 300 p.

5. Bech, I.D., Lysitsa, G.M., "Reflection in the spiritual self-development of personality", Pedagogics and psychology. Bulletin of the National Academy of Sci- ences of Ukraine, PJSC "Publishing House" Kyivska Pravda, pp. 37.

6. Bizyayeva, A.A. (2004), Psihologija myshlenija pedagoga: Pedagogicheskaja refleksija [Psychology of Thinking Teacher: Pedagogical Reflection], PGPI, Pskov, Russia.

7. Dzhaksylykova, U.S. (2015), Rol' refleksii v professional'nom stanovlenii pedagoga [The role of reflection in the professional development of the teacher], Retrieved from: http://zkoipk.kz/2015smart1/1282conf.html.

8. Drujilov, S.A. (2010), "Individual resource of professional development as an essential condition for the development of professionalism of a person", International Journal of Applied and Fundamental Research, No. 5, pp. 145-148.

9. Zimnaya, I. A. (2000), Pedagogicheskaja psihologija: Uchebnik dlja vuzov [Pedagogical Psychology: textbook for high schools], Logos, Moscow, Russia.

10. Zyazun, I.A., Kramuschenko, L.V., Kryvonos, 
I. F. (2004), Pedahohichna maisternist: Pidruchnyk (2e vydannia., Pratsi.) [Pedagogical Proficiency: Textbook (2nd Edition., Proceedings.)], Higher school, Kiev, Ukraine.

11. Isaev, E.I., Kosaretsky, S.G., Slobodchikov, V.I. (2000), "Formation and development of professional consciousness of future teacher", Vopr. psychology, No.3, pp. 57-66.

12. Kulyutkin, Y.N., Sukhobskaya, G.S. (2000), Obrazovanie vzroslyh: social'no-psihologicheskie problemy, poiski, reshenija [Education of adults: sociopsychological problems, searches, solutions], IW RAO, St. Petersburg, Russia..

13. Ponomarev, O.S. (2006), Model profesiinoi diialnosti fakhivtsia: (tekst lektsii) [Model of professional activity of a specialist: (text of a lecture)], NTU "KhPI", Kharkiv, Ukraine.

14. "About higher education, Law of Ukraine dated July 1, 2014. № 1556-VII”, (2014), The Verkhovna Rada of Ukraine: officer. web portal,Text. Data Kyiv, 2014, Retrieved from: http://zakon3.rada.gov.ua/ laws / show / 1556-18 / page 6

15. Sas, N.N. (2015), "Professional reflection as a criterion for the effectiveness of vocational training for innovative management in the conditions of the master's degree "Specific categories. Management of Educational Institutions ", Articles and reports of participants of the international scientific and practical conference" Innovative development - from J. Schumpeter to the present: economy and education "Kaluga, October 1-2, 2015, Publishing house "Scientific consultant", pp. 352-354.

16. Semichenko, V.A. (2001), Psykholohiia osobystosti [Psychology of personality], Publisher Eshke, Kiev, Ukraine.

17. Billodid, I.K.(ed.) (1978), "The Ukrainian language dictionary: 11 volumes", Academy of Sciences of the USSR, Institute of Linguistics. named after O. Potebni, T. 9, pp. 2.

18. Sukhobskaya, G.S., Shadrin, T. V. (2011), “An- dragogical orientation of vocational and pedagogical education: sociocultural prerequisites", Retrieved from: http:// ext. spb. ru/ index. php/2011-03-29-09-0314/108-custom-person.

19. Fetiskin, N.P., Kozlov, V.V., Manuilov, G. M. (2002), Social'no-psihologicheskaja diagnostika razvitija lichnosti $i$ malyh grupp [Social and psychological diagnostics of the development of personality and small groups], Moscow, Russia.

20. Fopel, K. (2003), Jeffektivnaja masterskaja.Dinamicheskoe Obuchenie [An effective workshop.Dynamic Learning], Genesis, Moscow, Russia.

21. Khutorskaya, A.V. (2001), Sovremennaja didaktika: Uchebnik dlja vuzov [Contemporary didactics: textbook for high schools], Peter, St. Petersburg, Russia.

22. Shynkaruk, V.I. (1986), Filosofskij Slovar' [Philosophical Dictionary], Heads. Ed. URE, Kiev, Ukraine.

23. Shchedrovitsky, G.P. (2004), "Reflexion and its problems", Reflexive processes and management, No.2, T. 4, pp. 72-77.

24. Yablonskaya, T.M. (1999), "The pedagogical reflection training for students and teachers / T.M.Yablonskaya", Practical psychology and social work, No.3, pp. 9-12.

25. Hatton, N., Smith, D. (1995), "Reflection in teacher education: Towards definition and implementation", Teaching Education, No 11(1), pp. 33-39.

26. Kelly, M. "Importance of Teacher Reflection", URL: https://www.thoughtco.com/importance-ofteacher-reflection-8322.

27. Richards, J. (1990), "Beyond training: Approaches to teacher education in language teaching", Language Teacher, No 14(2), pp. 3-8.

28. Farrell, T. (1998), "Reflective teaching", Forum ELT Journal, № 4, pp. 10-18. 